\title{
Polyurea Dendrimer Folate-Targeted Nanodelivery of L-Buthionine Sulfoximine as a Tool to Tackle Ovarian Cancer Chemoresistance
}

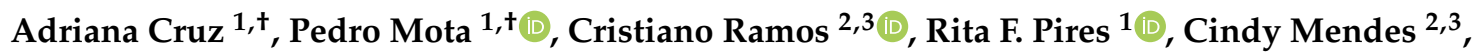 \\ José P. Silva ${ }^{4}\left(\mathbb{D}\right.$, Sofia C. Nunes ${ }^{2,3} \mathbb{D}_{\text {, }}$, Vasco D. B. Bonifácio ${ }^{1, *,+} \mathbb{D}$ and Jacinta Serpa ${ }^{2,3, *,+}$ \\ 1 iBB-Institute for Bioengineering and Biosciences, Instituto Superior Técnico, Universidade de Lisboa, \\ Avenida Rovisco Pais, 1049-001 Lisboa, Portugal; ab.cruz@campus.fct.unl.pt (A.C.); \\ pedromb.mota@gmail.com (P.M.); ritafpires@tecnico.ulisboa.pt (R.F.P.) \\ 2 CEDOC, Chronic Diseases Research Centre, NOVA Medical School, Faculdade de Ciências Médicas, \\ Universidade NOVA de Lisboa, Campo dos Mártires da Pátria, 130, 1169-056 Lisboa, Portugal; \\ ramos.cristiano.93@gmail.com (C.R.); cindymendes8@gmail.com (C.M.); asofianunes5@gmail.com (S.C.N.) \\ 3 Instituto Português de Oncologia de Lisboa Francisco Gentil (IPOLFG), Rua Prof Lima Basto, 1099-023 \\ Lisboa, Portugal \\ 4 Hospital Santo António dos Capuchos, Centro Hospitalar Lisboa Central, Alameda Santo António dos \\ Capuchos, 1169-050 Lisboa, Portugal; jospais@gmail.com \\ * Correspondence: vasco.bonifacio@tecnico.ulisboa.pt (V.D.B.B.); jacinta.serpa@nms.unl.pt (J.S.) \\ + These authors contributed equally to this work.
}

Received: 20 December 2019; Accepted: 31 January 2020; Published: 3 February 2020

\begin{abstract}
Ovarian cancer is a highly lethal disease, mainly due to chemoresistance. Our previous studies on metabolic remodeling in ovarian cancer have supported that the reliance on glutathione (GSH) bioavailability is a main adaptive metabolic mechanism, also accounting for chemoresistance to conventional therapy based on platinum salts. In this study, we tested the effects of the in vitro inhibition of GSH synthesis on the restoration of ovarian cancer cells sensitivity to carboplatin. GSH synthesis was inhibited by exposing cells to L-buthionine sulfoximine (L-BSO), an inhibitor of $\gamma$-glutamylcysteine ligase (GCL). Given the systemic toxicity of L-BSO, we developed a new formulation using polyurea (PURE) dendrimers nanoparticles (L-BSO@PURE $\mathrm{G}_{4}-\mathrm{FA}_{2}$ ), targeting L-BSO delivery in a folate functionalized nanoparticle.
\end{abstract}

Keywords: ovarian cancer; chemoresistance; L-buthionine sulfoximine; polyurea dendrimers; carboplatin; nanoparticles-mediated chemotherapy; chemosensitization

\section{Introduction}

Ovarian cancer is a highly mortal gynecologic cancer [1-3], with the late diagnosis and acquired chemoresistance to the conventional therapy as the major hurdles to cure this disease [4-6]. The conventional therapy of ovarian cancer is mainly based on comprehensive oxidative/alkylating drugs such as carboplatin in combination with taxanes [7-9]. The platinum drugs induce cell death through two mechanisms: the establishment of adducts of DNA and proteins, and the generation of reactive oxygen species (ROS) $[9,10]$. We have previously found that ovarian cancer cells exhibit a great metabolic reliance on cysteine and glutathione (GSH), as these thiols were shown to protect cells under stressful conditions such as hypoxia or carboplatin exposure, hence, also accounting for chemoresistance [11-13]. GSH can explain this protective effect given its role as a ROS scavenger and as a pivotal drug detoxifier, allowing cells to evade cell death [14-18]. We have reported that chemoresistance, supported by high GSH levels, can be abrogated upon the exposure to L-buthionine 
sulfoximine (L-BSO) [11], an inhibitor of $\gamma$-glutamylcysteine ligase (GCL), the first enzyme catalyzing the synthesis of GSH $[19,20]$. However, the systemic administration of L-BSO is associated to an elevated toxicity, since L-BSO is an irreversible inhibitor of GCL [19]. Therefore, an appropriate approach to revert this systemic toxicity would be the targeted delivery of L-BSO to cancer cells using a nanoparticles-mediated strategy. In this sense, dendrimers are an outstanding drug delivery platform, and many efforts have been made in the last few years to circumvent their cytotoxicity [21], encouraging the fast translation into clinic applications in a near future. In this study, we developed polyurea (PURE) dendrimers, which are a special case of non-toxic [22] and non-hemolytic dendrimers up to very high concentrations (circa $50 \mu \mathrm{M}$, unpublished data), and that have already been explored in different nanotherapeutic strategies [23-26]. The use of folate-targeted dendrimers is an emergent approach in cancer-targeted chemotherapy [27]. As we recently reported [28], folate-targeted polyurea dendrimer generation four ( $\left.\mathrm{PURE}_{\mathrm{G} 4}-\mathrm{FA}_{2}\right)$ nanoparticles are a suitable drug delivery system. Of notice, ovarian cancer cells express higher levels of folate receptor $\alpha(\mathrm{FA}-\mathrm{R} \alpha)$ than normal cells [29] and FA-R $\alpha$ targeted therapy is an assay commonly tested in in vitro and in vivo models of ovarian cancer [30]. In here, we hypothesized that $\mathrm{PURE}_{\mathrm{G} 4}-\mathrm{FA}_{2}$ encapsulated $\mathrm{L}-\mathrm{BSO}$ (L-BSO@PURE $\mathrm{G}_{4}-\mathrm{FA}_{2}$ ) is a suitable strategy to tackle carboplatin resistance, restoring ovarian cancer cells sensitivity to chemotherapy.

\section{Materials and Methods}

\subsection{Cell Culture}

Two human ovarian cancer cell lines were used, a serous carcinoma (OSC) cell line (OVCAR3-HTB-161 ${ }^{\mathrm{TM}}$ ) and a clear cell carcinoma (OCCC) cell line (ES2-CRL-1978 ${ }^{\mathrm{TM}}$ ). In order to analyze the effect of nanoparticles in squamous cells, since ovarian cancer metastasizes preferentially to peritoneum, an immortalized squamous epithelium cell line (HaCaT-PCS-200-011 ${ }^{\mathrm{TM}}$ ) was also tested. All the cell lines were obtained from American Type Culture Collection (ATCC) (Manassas, VA, USA) and were cultured in Dulbecco's Modified Eagel Medium (DMEM; 41965-039, Gibco, Life Technologies; Massachusetts, MA, USA). All culture media were supplemented with $10 \%$ fetal bovine serum (FBS; S 0615, Merck; Darmstadt, Germany), 1\% Antibiotic-Antimycotic (AA; P06-07300, PAN Biotech; Aidenbach, Germany) and 50 rg/mL gentamicin (15750-060, Gibco, Life Technologies; Massachusetts, MA, USA). Cells were maintained in a humidified environment of $5 \% \mathrm{CO}_{2}$ at $37^{\circ} \mathrm{C}$, until reaching approximately $75-100 \%$ optical confluence. Cells were detached with $0.05 \%$ Trypsin-EDTA (25300-054, Invitrogen, Thermo Fisher Scientific; Massachusetts, MA, USA) at room temperature (RT) for approximately $5 \mathrm{~min}$, and split to new plates according to the experimental procedures.

\subsection{Folate Receptor $\alpha(F A-R \alpha)$ Immunofluorescence}

Sections of $4 \%$ paraformaldehyde fixed and paraffin embedded cells (cyto-blocks) were used, after deparaffinization in xylol and re-hydration in a sequence of $5 \mathrm{~min}$ incubations in $100 \%, 70 \%$ and $40 \%$ ethanol, followed by $10 \mathrm{~min}$ in water. Slides were then incubated with the mouse-anti-human FA-R $\alpha$ (IPI3005G10, BioCare Medical; Pacheco, CA, USA) for $3 \mathrm{~h}$ at RT; followed by incubation with the rabbit-anti-mouse Alexa Fluor ${ }^{\circledR}$ 488-conjugated secondary antibody (A-28175, Invitrogen; Massachusetts, MA, USA), $1 \mathrm{~h}$, in the dark, at RT. Slides were mounted in VECTASHIELD media containing DAPI (4'-6-diamidino-2-phenylindole) to counterstain cell nuclei in blue (H-1200, Vector Labs; Burlingame, CA, USA). The analysis was performed by standard fluorescence microscopy in an Axio Imager.Z1 microscope (Zeiss, Oberkochen, Germany). Images were acquired and processed with CytoVision software (Leica, Wetzlar, Germany).

\section{3. $\mathrm{L}-B S O$ and FL Encapsulation}

Polyurea (PURE) dendrimers were synthesized following our supercritical-assisted polymerization methodology [22]. FA-NHS and $\mathrm{PURE}_{\mathrm{G} 4}-\mathrm{FA}_{2}$ were synthesized following our reported protocol [31]. All chemicals and solvents were used as received without further purification. Folic acid 
(FA) and N,N-dicyclohexylcarbodiimide (DCC; A10973) (99\% purity) were obtained from Alfa Aesar (Kandel, Germany). Fluorescein (FL; F7505), Triethylamine (TEA; 471283) ( $\geq 99.5 \%$ purity), N-hydroxysuccinimide (NHS; 130672) (98\% Purity) and L-buthionine sulfoximine (L-BSO: B2515) ( $\geq 97 \%$ purity) were obtained from Sigma-Aldrich (Darmstadt, Germany).

The encapsulation of FL in PURE $\mathrm{G}_{4}-\mathrm{FA}_{2}\left(\mathrm{FL}_{\mathrm{PURE}} \mathrm{G}-\mathrm{FA}_{2}\right)$ followed the same methodology used for L-BSO encapsulation [31]. Typically, in a vial, FL $(0.0131 \mathrm{mmol}, 5.3 \mathrm{mg})$ was dissolved in $1 \mathrm{~mL}$ of distilled water. To this solution, the folate-target dendrimer ( $\left.\mathrm{PURE}_{\mathrm{G} 4}-\mathrm{FA}_{2}\right)(6.46 \mu \mathrm{mol}, 56.6 \mathrm{mg})$ was added. The mixture was then left overnight at RT, in the dark, and under stirring. After this period, the product was purified by dialysis (MWCO $100-500 \mathrm{Da}$ ) and characterized by ${ }^{1} \mathrm{H}$ NMR.

\subsection{Confirmation of Cellular Internalization of Nanoparticles by Flow Cytometry}

Cells $\left(1 \times 10^{5}\right.$ cells/well $)$ were cultured overnight on 24-well plates and then incubated with several concentrations of FL@PURE $\mathrm{G}_{4}-\mathrm{FA}_{2}(0.001-0.120 \mu \mathrm{M})$ for $24 \mathrm{~h}$. Only viable adherent cells were collected for the analysis. Cells were then washed with PBS $(1 \times)$ and detached with trypsin-EDTA. After collection to $1.5 \mathrm{~mL}$ Eppendorfs, cells were harvested by centrifugation at $255 \times g$ for $3 \mathrm{~min}$ and washed twice with PBS (1X). Afterwards, cells were suspended in $200 \mu \mathrm{L}$ of PBS (1X) and samples were analyzed by flow cytometry (FACScalibur-Becton Dickinson; New Jersey, NJ, USA). Sample data was analyzed using FlowJo 8.7 software (https://www.flowjo.com). The assay was performed at least in three biological replicates.

\subsection{Confirmation of Cellular Internalization of Nanoparticles by Fluorescence Microscopy}

The cell lines OVCAR3, ES2 and HaCaT were cultured on glass slides coated with $0.2 \%$ gelatine and then incubated with free FL or FL@PURE $\mathrm{G}_{4}-\mathrm{FA}_{2}$, for 8 and $24 \mathrm{~h}$. After incubation, cells were fixed in $2 \%$ paraformaldehyde for $15 \mathrm{~min}$ at RT and washed with PBS $(1 \times)$. The slides were mounted in VECTASHIELD media with DAPI and examined by standard fluorescence microscopy using an Axio Imager.Z1 microscope. The images were acquired with the CytoVision software. The assay was performed at least in three biological replicates.

\subsection{Cell Death Analysis by Flow Cytometry}

The cells $\left(1 \times 10^{5}\right.$ cells/well $)$ were seeded in 24-well plates and cultured overnight in control conditions. The effect of different concentrations of free L-BSO (between 0.05 and $120 \mathrm{mM}$ ) and L-BSO@PURE ${ }_{\mathrm{G} 4}-\mathrm{FA}_{2}$ (between 3 and $2522 \mu \mathrm{M}$ ) in cell viability was tested for $24 \mathrm{~h}$ of exposure. To evaluate the sensitization effect of L-BSO to carboplatin, OVCAR3 cells were exposed to the previous culture conditions combined with carboplatin $(25 \mu \mathrm{g} / \mathrm{mL})$.

After experimental conditions, the detached cells in supernatants were collected, and adherent cells were harvested with $0.05 \%$ Trypsin-EDTA. Cells in the supernatant and trypsinized cells were harvested together by centrifugation, $255 \times g$ for $2 \mathrm{~min}$. Cells were stained with $0.5 \mu \mathrm{L}$ annexin V-fluorescein (FITC)-(640906, BioLegend, San Diego, CA, USA), in $1 \times$ annexin V binding buffer (10 mM HEPES- $\mathrm{pH} 7.4,150 \mathrm{mM} \mathrm{NaCl}, 2.5 \mathrm{mM} \mathrm{CaCl}_{2}$, prepared in $1 \times \mathrm{PBS}-\mathrm{pH} 7.4$ ), and incubated at RT, in the dark, for $15 \mathrm{~min}$. Samples were resuspended in $200 \mu \mathrm{L}$ PBS $(1 \times)$ plus $1 \%$ BSA and centrifuged at $255 \times \mathrm{g}$ for $2 \mathrm{~min}$. Cells were resuspended in $200 \mu \mathrm{L}$ of annexin $\mathrm{V}$ binding buffer $1 \times$ and $2.5 \mu \mathrm{L}$ of propidium iodide (PI, $50 \mu \mathrm{g} / \mathrm{mL}$; P4170, Sigma-Aldrich; Darmstadt, Germany) was added 5 min prior to analysis. Afterwards, samples were analyzed by flow cytometry (FACScalibur-Becton Dickinson; Franklin Lakes, NJ, USA). Data were analyzed using FlowJo 8.7 software (https://www.flowjo.com). The assay was performed at least in three biological replicates.

\subsection{Statistical Analysis}

Statistical analyses were performed in GraphPad Prism 7.0 software (www.graphpad.com). Data is presented as mean $\pm \mathrm{SD}$. Assays were performed with at least three biological replicates. For comparisons of two groups, two-tailed unpaired $t$-test was used. To compare more than two 
groups, one-way and two-way analysis of variance (ANOVA) with Dunnets multiple-comparisons test were used. Statistical significance was established at $p<0.05 ;^{*} p<0.05,{ }^{* *} p<0.01,{ }^{* * *} p<0.001,{ }^{* * *} p$ $<0.0001$.

\section{Results}

\subsection{Ovarian Cancer Cells Internalize PURE $\mathrm{G}_{4}-F A_{2}$ Nanoparticles in a Dose Dependent Manner}

The expression of FA-R $\alpha$ was confirmed in ovarian cancer (ES2 and OVCAR3) and squamous non-cancer $(\mathrm{HaCaT})$ cell lines. As seen, HaCaT cell are negative for FA-R $\alpha$, whereas ES2 and OVCAR3 cells express FA-R $\alpha$ (Figure 1A). In order to validate the specificity of the internalization of PURE $\mathrm{G}_{4}-\mathrm{FA}_{2}$ by ovarian cancer cells, we tested fluorescein loaded PURE $\mathrm{G}_{4}-\mathrm{FA}_{2}\left(\mathrm{FL} @ \mathrm{PURE} \mathrm{G}_{4}-\mathrm{FA}_{2}\right)$ prior to test L-BSO@PURE $\mathrm{G}_{4}-\mathrm{FA}_{2}$. By flow cytometry and fluorescence microscopy, we verified that FL is delivered in a dose dependent manner to both ES2 and OVCAR3 cell lines (Figure 1). In HaCaT cells, the internalization of fluorescein was only verified at the highest concentration $(1 \mu \mathrm{M})$ of FL@PURE $\mathrm{G}_{4}-\mathrm{FA}_{2}$, after 8 and $24 \mathrm{~h}$ (Figure 1C,D). This observation supports the affinity of FL@PURE $\mathrm{G}_{4}-\mathrm{FA}_{2}$ to ovarian cancer cells.

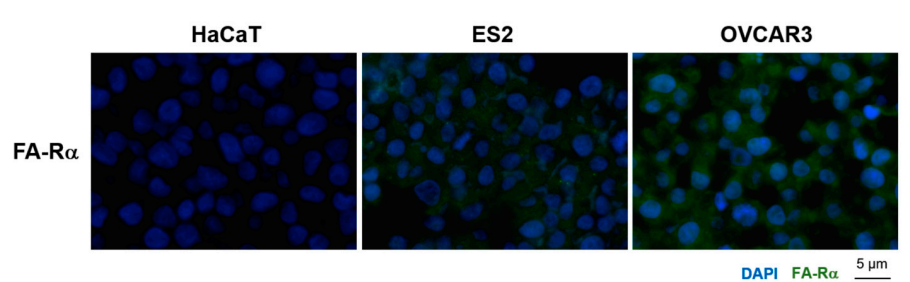

B

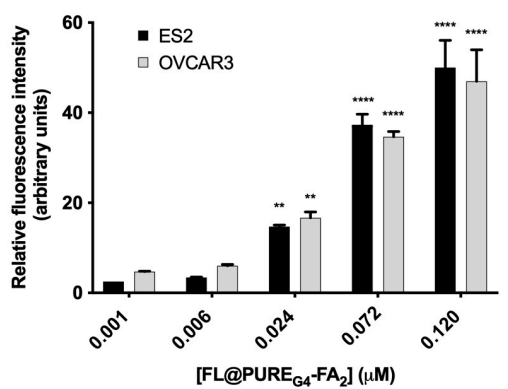

C

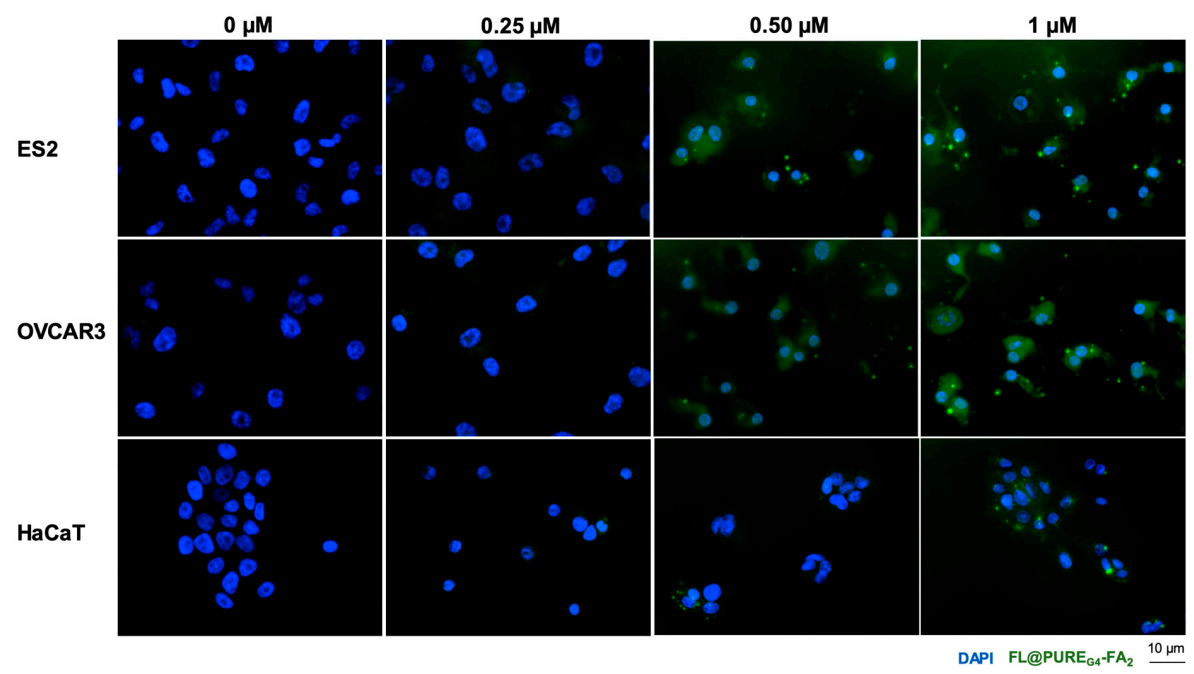

Figure 1. Cont. 
D

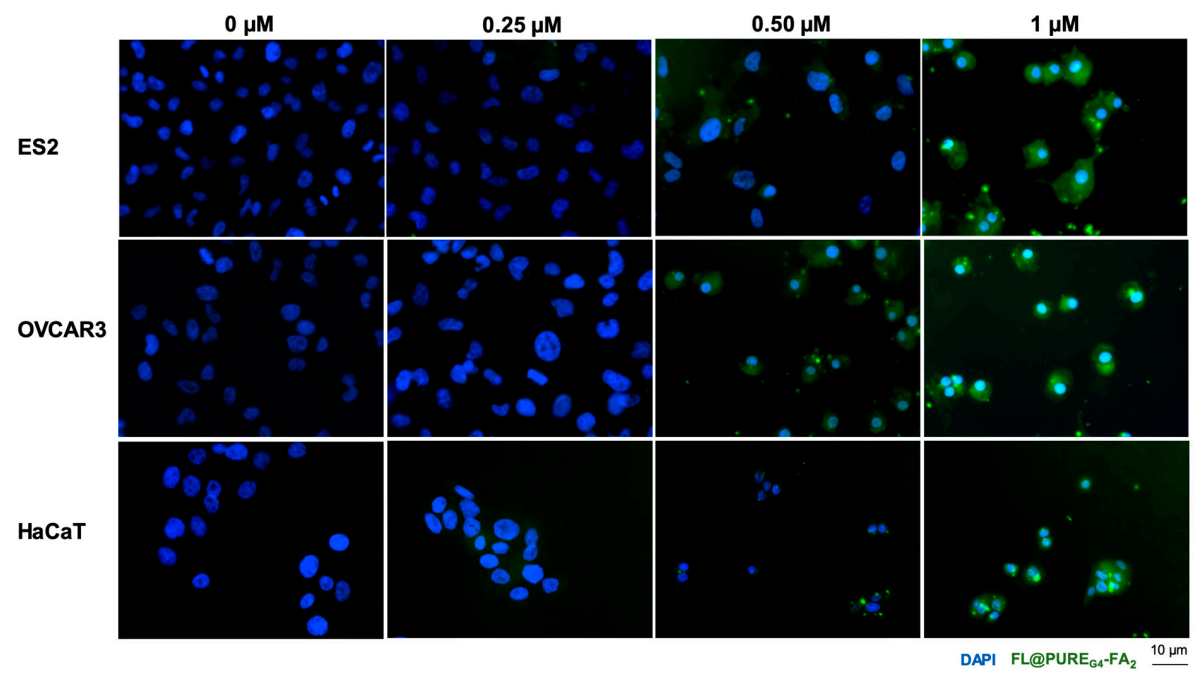

Figure 1. Ovarian cancer cells internalize FL@PURE $\mathrm{G}_{4}-\mathrm{FA}_{2}$ nanoparticles in a dose dependent manner. The expression of folate receptor $\alpha(\mathrm{FA}-\mathrm{R} \alpha)$ was evaluated by immunofluorescence in HaCaT, ES2 and OVCAR3 cells (A). Ovarian cancer cells (OVCAR3 and ES2) were exposed to different concentrations of $\mathrm{PURE}_{\mathrm{G} 4}-\mathrm{FA}_{2}$ nanoparticles loaded with fluorescein (FL@PURE $\mathrm{G}_{4}-\mathrm{FA}_{2}$ ) and the cellular internalization was confirmed by: (B) FL fluorescence detected by flow cytometry (after $24 \mathrm{~h}$ of incubation); and by fluorescence microscopy (C) after $8 \mathrm{~h}$ and (D) $24 \mathrm{~h}$ of incubation. HaCaT cells were used as a control in fluorescence microscopy. In immunofluorescence, nuclei were DAPI (4',6-diamidino-2-phenylindole) counterstained. Results are shown as mean $\pm \mathrm{SD}$. ${ }^{* *} p \leq 0.01^{* * * *} p \leq 0.0001$.

3.2. $\mathrm{L}-B S O @ P U R E_{G 4}-F A_{2}$ is More Effective in Inducing Cell Death in Ovarian Cancer Cells than Free $\mathrm{L}-B S O$

The efficacy of inducing cell death by free and encapsulated L-BSO was tested in ovarian cancer cells, in order to verify the advantages of using a L-BSO targeted delivery. In ovarian cancer cells, the concentration needed to reach $50 \%$ of the maximum cytotoxic effect $\left(\mathrm{EC}_{50}\right)$ was higher in free L-BSO than in L-BSO@PURE ${ }_{\mathrm{G} 4}-\mathrm{FA}_{2}$, indicating a more effective delivery of L-BSO by the L-BSO@PURE $\mathrm{G}_{4}-\mathrm{FA}_{2}$ nanoformulation in comparison to free L-BSO applied directly to the culture media (Figures 2 and 3 ). The $\mathrm{EC}_{50}$ of L-BSO@PURE ${ }_{\mathrm{G} 4}-\mathrm{FA}_{2}$ was 22-fold (ES2) and 81-fold (OVCAR3) lower than the $\mathrm{EC}_{50}$ of free $\mathrm{L}-\mathrm{BSO}$ (Figure 2C,D and Figure 3C,D). Furthermore, ES2 cells revealed to be more resistant to the $\mathrm{L}-\mathrm{BSO}$ effect than OVCAR3, given the higher $\mathrm{EC}_{50}$ for L-BSO@PURE $\mathrm{G}_{4}-\mathrm{FA}_{2}$ and $\mathrm{L}-\mathrm{BSO}$ in this cell line compared to OVCAR3 (Figure 2C,D and Figure 3C,D). 
A

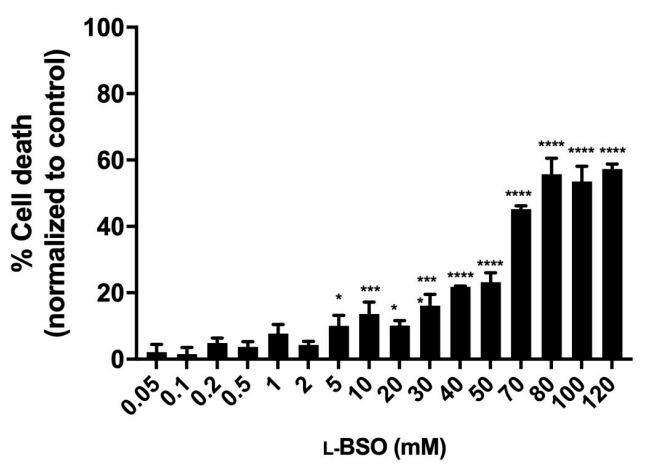

C

log-dose vs response

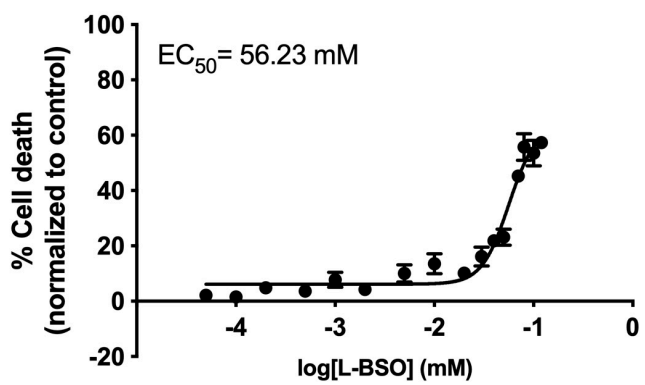

B

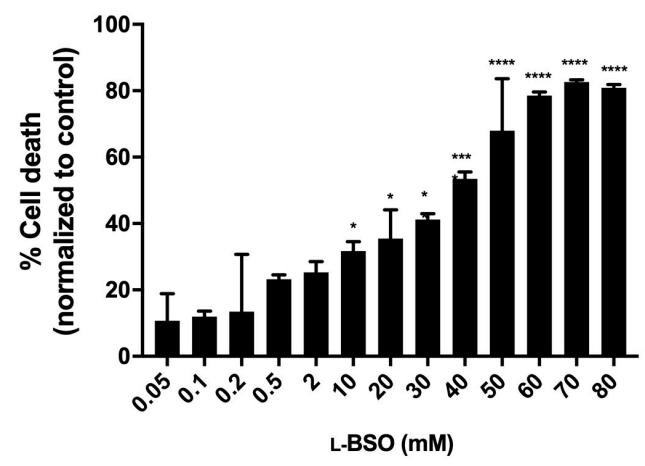

D

log-dose vs response

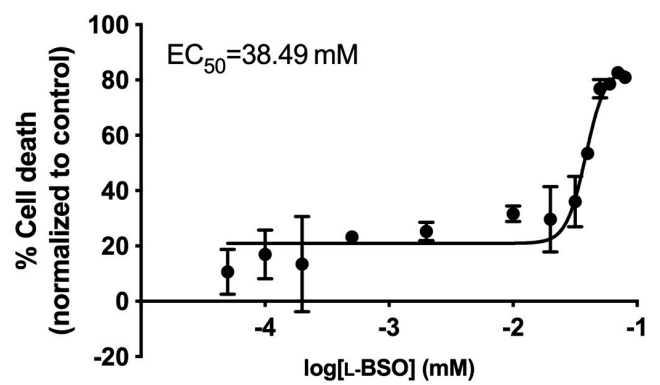

Figure 2. Free L-BSO induces cell death in ovarian cancer cells in a dose dependent manner in a mM scale. Ovarian cancer cells (OVCAR3 and ES2) were exposed to different concentrations of L-BSO and cell death was determined by flow cytometry using annexin V-FITC and propidium iodide (PI) staining. Cell death percentage related to ES2 cells (A) and OVCAR3 cells (B) is presented. The concentration of L-BSO needed to reach $50 \%$ of the maximum cytotoxic effect $\left(\mathrm{EC}_{50}\right)$ was also calculated: $(\mathbf{C}) \mathrm{EC}_{50}$ related to ES2 cells and (D) $\mathrm{EC}_{50}$ related to OVCAR3 cells. Results are shown as mean \pm SD. ${ }^{*} p \leq 0.05$ $* * * p \leq 0.001 * * * * 0.0001$. 
A

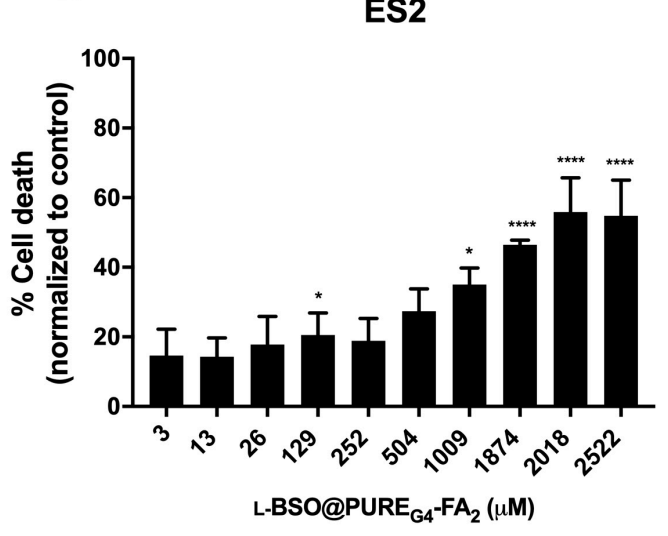

C

\section{log-dose vs response}

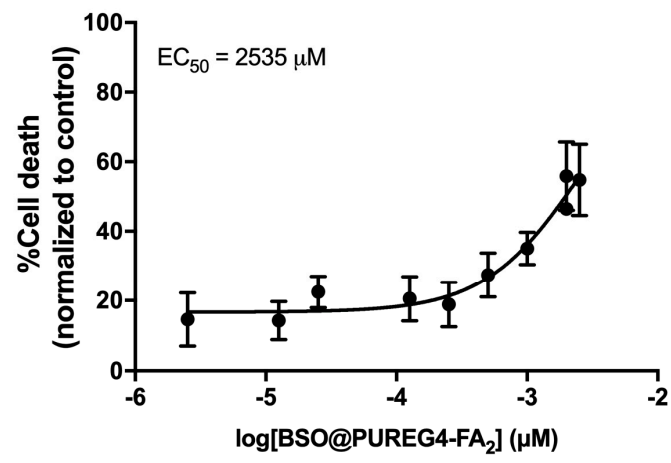

B

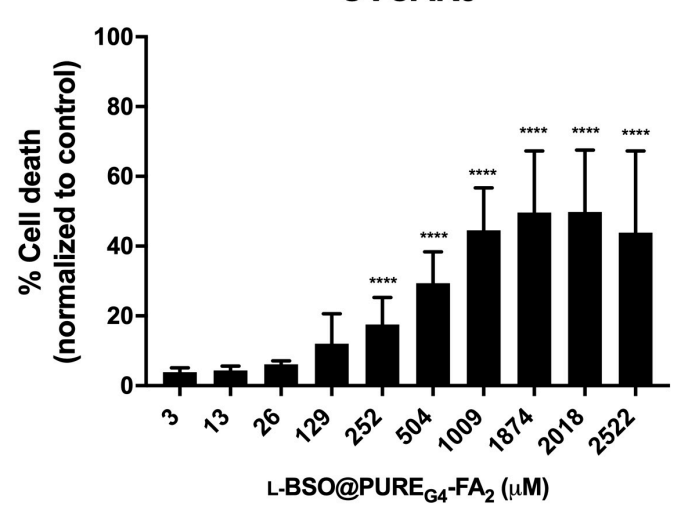

D

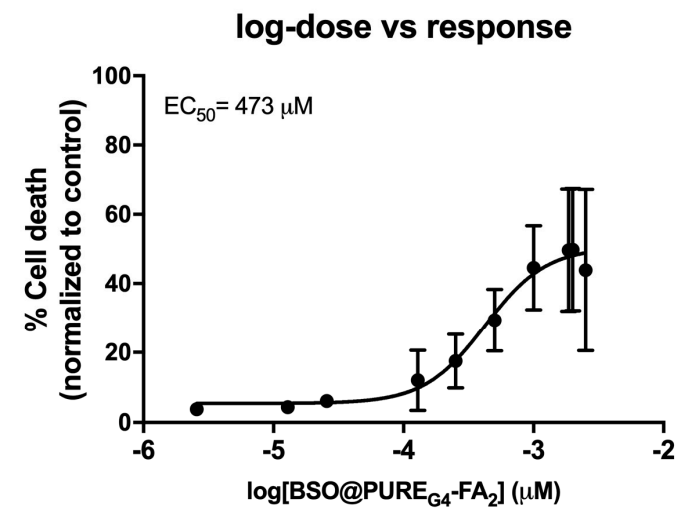

Figure 3. $\mathrm{L}-\mathrm{BSO} @ \mathrm{PURE}_{\mathrm{G} 4}-\mathrm{FA}_{2}$ induces cell death in ovarian cancer cells in a dose dependent manner in a $\mu \mathrm{M}$ scale. Ovarian cancer cells (OVCAR3 and ES2) were exposed to different concentrations of L-BSO loaded into PURE $\mathrm{G}_{4}-\mathrm{FA}_{2}$ nanoparticles (L-BSO@PURE $\mathrm{G}_{4}-\mathrm{FA}_{2}$ ) and cell death was determined by flow cytometry using annexin V-FITC and propidium iodide (PI) staining. Cell death percentage related to ES2 cells $(\mathbf{A})$ and OVCAR3 cells $(\mathbf{B})$ is presented. The concentration of $\mathrm{L}-\mathrm{BSO} @ \mathrm{PURE}_{\mathrm{G} 4}-\mathrm{FA}_{2}$ needed to reach $50 \%$ of the maximum cytotoxic effect $\left(\mathrm{EC}_{50}\right)$ was also calculated: (C) $\mathrm{EC}_{50}$ related to ES2 cells and (D) $\mathrm{EC}_{50}$ related to OVCAR3 cells. Results are shown as mean $\pm \mathrm{SD}$. ${ }^{*} p \leq 0.05,{ }^{* * * *} p \leq 0.0001$.

\subsection{L-BSO@PURE $E_{G 4}-F A_{2}$ Is More Cytotoxic to Ovarian Cancer Cells than to Non-Cancer Squamous Cells}

L-BSO@PURE ${ }_{\mathrm{G} 4}-\mathrm{FA}_{2}$ was also tested in non-cancer squamous cells, as an attempt to address the effect in the peritoneal squamous cells, trying to anticipate a future therapy applied by intra-abdominal infusion. Thus, the cell death levels in $\mathrm{HaCaT}$ cells were evaluated upon exposure to $\mathrm{L}-\mathrm{BSO} @ P U R E_{\mathrm{G} 4}-\mathrm{FA}_{2}$, and no differences were observed between cells exposed to different concentrations of $\mathrm{L}-\mathrm{BSO} @ \mathrm{PURE}_{\mathrm{G} 4}-\mathrm{FA}_{2}$ (Figure 4). Interestingly, the highest concentration tested $(1000 \mu \mathrm{M})$ induced about $10 \%$ of cell death in squamous cells, whereas the same concentration induced more than $40 \%$ of cell death in ovarian cancer cells (Figure 3A,B and Figure 4). This result supports that L-BSO targeted delivery can be a good strategy to treat ovarian cancer without strongly affecting non-cancer cells, at least in a re-sensitizing therapeutic protocol to overcome resistance to platinum salts. 


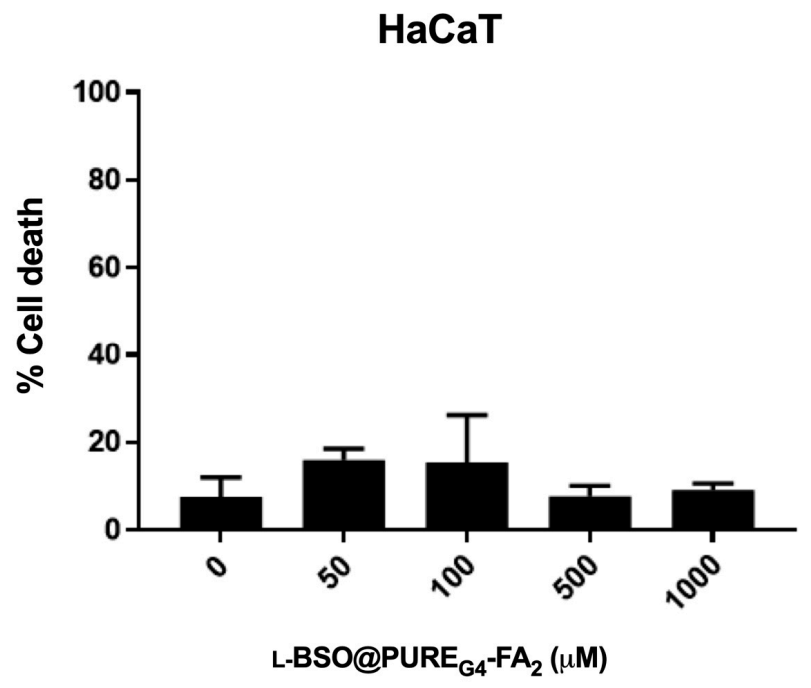

Figure 4. L-BSO@PURE $\mathrm{G}_{4}-\mathrm{FA}_{2}$ does not induce cell death in non-cancer squamous cells (HaCaT). $\mathrm{HaCaT}$ cells were exposed to different concentrations of $\mathrm{L}-\mathrm{BSO}$ loaded into $\mathrm{PURE}_{\mathrm{G}_{4}-\mathrm{FA}_{2} \text { nanoparticles }}$ (L-BSO@PURE $\mathrm{G}_{4}-\mathrm{FA}_{2}$ ) and cell death percentage was determined by flow cytometry using annexin $\mathrm{V}$-FITC and propidium iodide (PI) staining. Results are shown as mean \pm SD.

\subsection{L-BSO@PURE $E_{G 4}-F A_{2}$ Is Effective in Increasing the Sensitivity of Ovarian Cancer Cells to Carboplatin}

To validate our re-sensitizing approach, the OVCAR3 ovarian cancer cell line was exposed to increasing concentrations of L-BSO@PURE $\mathrm{G}_{4}-\mathrm{FA}_{2}$ separately or combined with carboplatin. Overall, L-BSO@PURE $\mathrm{G}_{4}-\mathrm{FA}_{2}$ exposure improved the cytotoxic effect of carboplatin. Furthermore, L-BSO@PURE ${ }_{\mathrm{G} 4}-\mathrm{FA}_{2}$ by itself increased cell death, showing again the reliance of ovarian cancer cells on GSH bioavailability (Figure 5). However, the highest concentrations of L-BSO@PURE ${ }_{G 4}-\mathrm{FA}_{2}$ did not improve carboplatin cytotoxicity, which can be related to the threshold of cell capacity of internalizing nanoparticles.

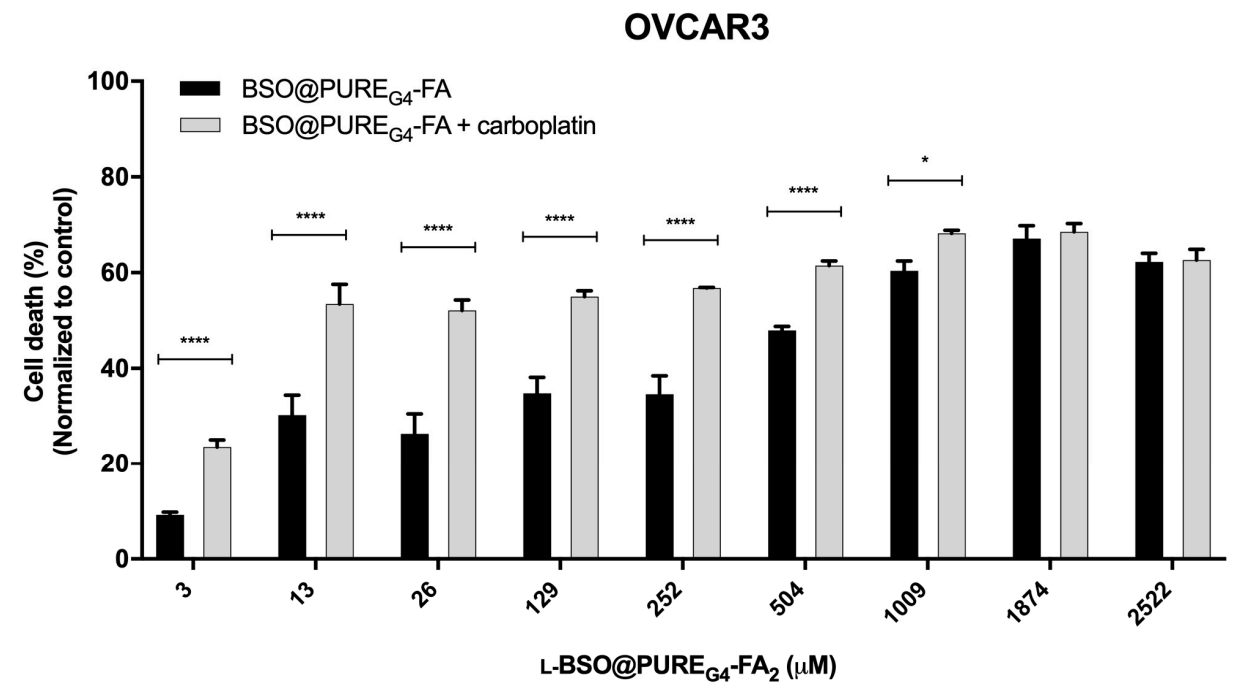

Figure 5. L-BSO@PURE $\mathrm{G}_{4}-\mathrm{FA}_{2}$ sensitizes ovarian cancer cells to carboplatin toxicity. Ovarian cancer cells (OVCAR3) were exposed to increased concentrations of L-BSO@PURE $\mathrm{G}_{4}-\mathrm{FA}_{2}$ with and without carboplatin $(25 \mu \mathrm{g} / \mathrm{mL})$. Cell death was determined by flow cytometry using annexin V-FITC and propidium iodide (PI) staining. Results are shown as mean \pm SD. ${ }^{*} p \leq 0.05^{* * * *} p \leq 0.0001$. 


\section{Discussion}

Acquired chemoresistance is a critical issue in oncology and ovarian cancer is a paradigm of this matter. Therefore, the development of strategies to overcome chemoresistance is required for a more effective treatment of ovarian cancer $[8,15,32,33]$. Following our insights on ovarian cancer metabolic remodeling and therapy response [11-13], we posited that a FA-R $\alpha$-targeted delivery of L-BSO can be a promising strategy to revoke resistance to carboplatin (Figure 6).

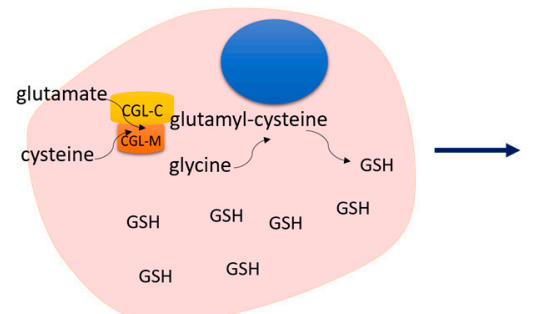

GSH

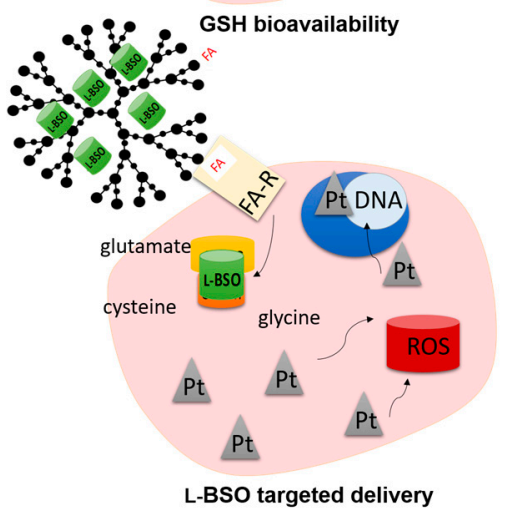

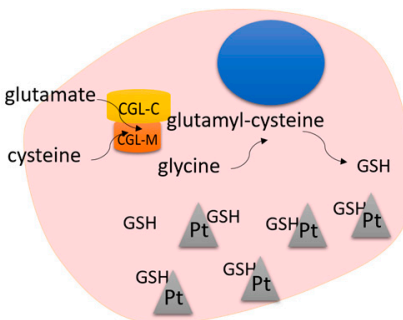

Chemoresistance

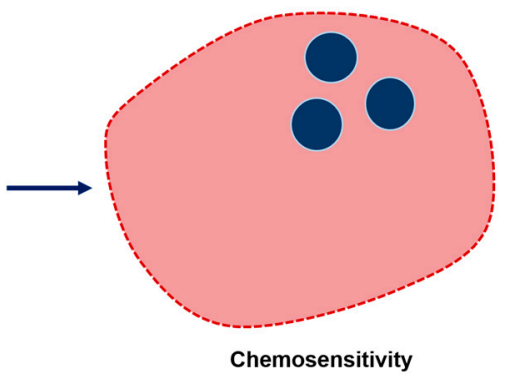

Figure 6. Rational of L-BSO@PURE $\mathrm{G}_{4}-\mathrm{FA}_{2}$ sensitization to carboplatin toxicity in chemoresistant cancer cells. Cancer cells presenting a high glutathione (GSH) bioavailability are commonly resistant to platinum salts $(\mathrm{Pt}$ ) toxicity, since GSH is a reactive oxygen species (ROS) scavenger and a xenobiotic detoxifying system. L-Buthionine sulfoximine (L-BSO) is an irreversible inhibitor of $\alpha$-glutamylcysteine ligase (GCL; which has catalytic and modulator subunits, GCLC and GCLM) responsible for GSH synthesis. The targeted delivery of L-BSO in folate-functionalized polyurea dendrimer generation four $\left(\mathrm{PURE}_{\mathrm{G} 4}-\mathrm{FA}_{2}\right.$ ) nanoparticles, taking advantage of the increased expression of FA-R $\alpha$ in cancer cells, will be efficiently internalized, inhibiting the synthesis of GSH. Therefore, carboplatin will act through its mechanisms of action, ROS generation and adducts formation, culminating in cancer cells death.

We have previously shown the efficacy of $\mathrm{PURE}_{\mathrm{G} 4}-\mathrm{FA}_{2}$ nanoparticles as a vehicle to deliver a cytotoxic selenium-chrysin compound to ovarian cancer cells [28]. In this study, we have shown the efficacy of those nanoparticles as a vehicle to delivery also L-BSO to ovarian cancer cells. By using fluorescein loaded PURE $\mathrm{G}_{4}-\mathrm{FA}_{2}$, we verified that ovarian cancer cells are more competent in the internalization of these nanoparticles when compared to non-cancer cells. The observed fluorescein uptake by non-cancer squamous cells at the highest tested concentration can be explained by the use of static cultures and by the fact that after $24 \mathrm{~h}$ some particles can adsorb to the cells in a nonspecific way. Nevertheless, our results confirmed that the high levels of FA-R $\alpha$ expression by cancer cells [29] can be explored as a way to reduce the effect of L-BSO in non-cancerous cells. Indeed, this fact allows a preservative systemic therapeutic approach, since L-BSO also induces GSH depletion [34,35] in normal cells, thus, rendering L-BSO otherwise too toxic for therapy. In the early 1990s, L-BSO was used as a drug to treat cancer [36,37], but its adverse effects were so severe that its use was promptly interrupted. However, more recently, L-BSO has regained attention, and several studies reported the use of this compound in cancer preclinical models [38-42]. 
Prior to this study, we demonstrated that free L-BSO efficiently diminishes GSH bioavailability, impairing resistance to carboplatin [11]. Importantly, this effect of L-BSO was also observed in an in vivo model of ovarian cancer, reducing significantly subcutaneous tumor size and GSH levels, as well as peritoneal dissemination [11]. In the present study, we verified that a $\mathrm{L}-\mathrm{BSO} @ \mathrm{PURE}_{\mathrm{G} 4}-\mathrm{FA}_{2}$ nanoformulation (Figure 7) is more effective in inducing ovarian cancer cells death than free L-BSO; and that ovarian cancer cells are more sensitive to $\mathrm{L}-\mathrm{BSO} @ \mathrm{PURE}_{\mathrm{G} 4}-\mathrm{FA}_{2}$ than non-cancer squamous cells $(\mathrm{HaCaT})$, reinforcing a putative therapy mediated by abdominal infusion.

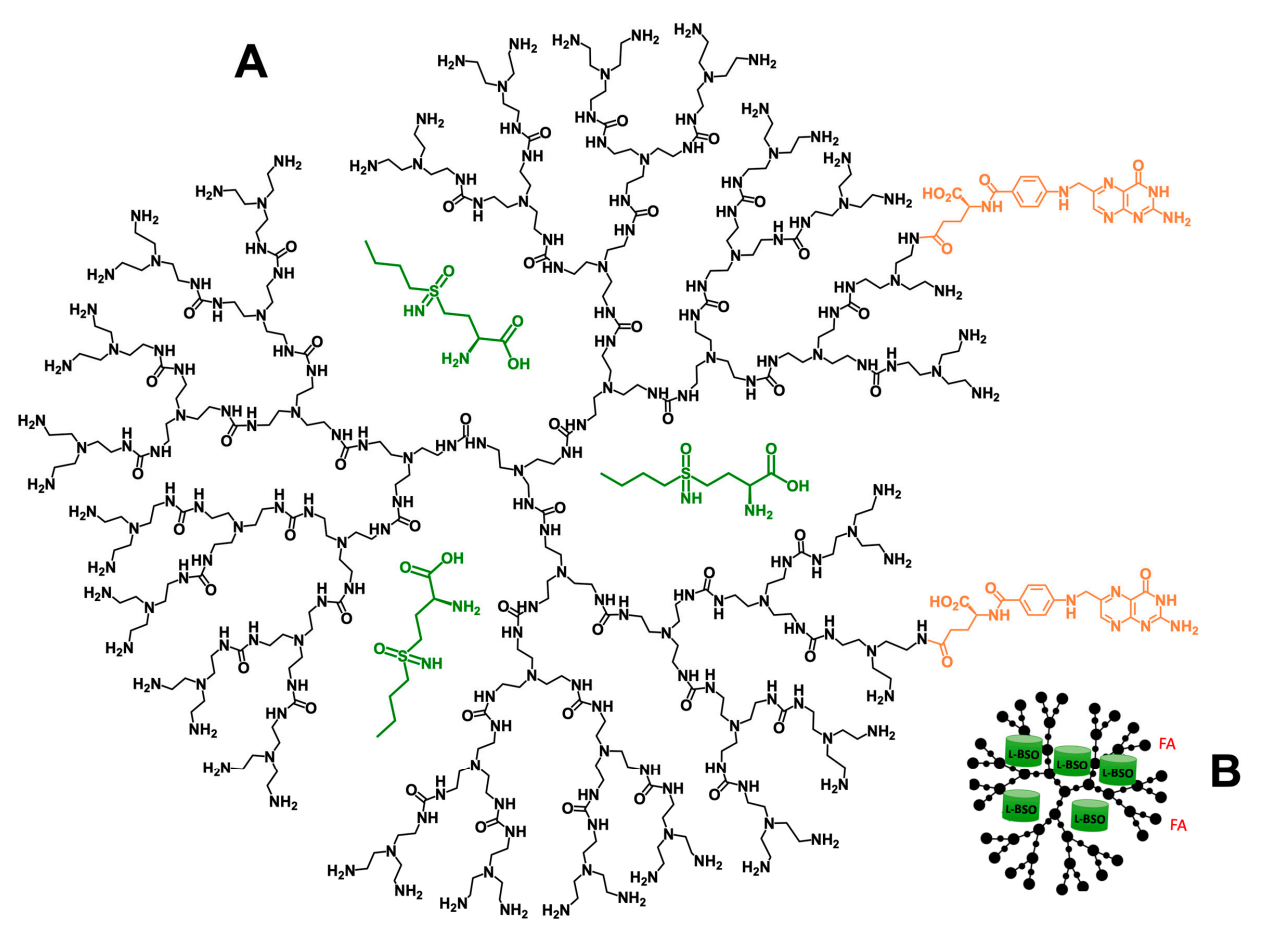

Figure 7. L-BSO@PURE $\mathrm{G}_{4}-\mathrm{FA}_{2}$ nanoformulation. Chemical (A) and cartoon (B) representation of the nanoformulation. L-BSO (green color) is encapsulated in a folate-targeted (orange color) generation four polyurea dendrimer $\left(\mathrm{PURE}_{\mathrm{G} 4}-\mathrm{FA}_{2}\right)$.

Our previous studies suggested a stronger dependence of ES2 cells on GSH turnover compared with OVCAR3 cells [12,13], which was also evidenced in this study, as higher $\mathrm{EC}_{50}$ of free L-BSO and L-BSO@PURE ${ }_{G 4}-F_{2}$ were determined for ES2 compared with OVCAR3 cells. Furthermore, concerning resistance to carboplatin, we have reported that upon carboplatin exposure ES2 produce higher levels of GSH [11] together with an accelerated GSH turnover, compared with OVCAR3 [28]. Therefore, our greatest achievements in this study were the effective use of $\mathrm{L}-\mathrm{BSO} @ \mathrm{PURE}_{\mathrm{G} 4}-\mathrm{FA}_{2}$ nanoparticles to the specific targeting of malignant cells, decreasing the harmful effects of L-BSO in non-malignant cells, and the similar effective targeting of ovarian cancer cells with different levels of chemoresistance. Together, our study supports the use of L-BSO@PURE $\mathrm{G}_{4}-\mathrm{FA}_{2}$ nanoparticles as a powerful strategy for ovarian cancer treatment.

\section{Conclusions}

More validation studies, namely in vivo assays, aiming to evaluate the systemic cytotoxic effect of L-BSO@PURE $\mathrm{G}_{4}-\mathrm{FA}_{2}$, are needed. Nevertheless, our study points out this new nanoformulation as a way of avoiding L-BSO systemic toxicity, and as a tool to abolish cancer cells resistance to carboplatin or putatively to other alkylating/oxidative drugs. In the future, this approach may be applied to other chemoresistant cancers. 
Author Contributions: A.C. and P.M. planned, performed and validated experiments; C.R. and R.F.P. performed experiments and supervised the technical execution, C.M. and J.P.S. performed experiments; S.C.N. supervised and validated some experiments, V.D.B.B. and J.S. are responsible for the design, first draft of the manuscript and conception of the research line. All authors have read and agreed to the published version of the manuscript.

Funding: The research was funded by iNOVA4Health-UID/Multi/04462/, a program financially supported by the Fundação para a Ciência e a Tecnologia-Ministério da Educação e Ciência (FCT-MCTES), through national funds and co-funded by FEDER under the PT2020 Partnership Agreement. We also acknowledge funding from FCT-MCTES through the project DREAM-PTDC/MEC-ONC/29327/2017 and FAI2017 from IPOLFG internal funding.

Conflicts of Interest: The authors declare no conflict of interest.

\section{References}

1. Jayson, G.C.; Kohn, E.C.; Kitchener, H.C.; Ledermann, J.A. Ovarian cancer. Lancet 2014, 384, $1376-1388$. [CrossRef]

2. Reid, B.M.; Permuth, J.B.; Sellers, T.A. Epidemiology of ovarian cancer: A review. Cancer Biol. Med. 2017, 14, 9-32. [PubMed]

3. Webb, P.M.; Jordan, S.J. Epidemiology of epithelial ovarian cancer. Best Pract. Res. Clin. Obstet. Gynaecol. 2017, 41, 3-14. [CrossRef] [PubMed]

4. Brasseur, K.; Gévry, N.; Asselin, E. Chemoresistance and targeted therapies in ovarian and endometrial cancers. Oncotarget 2017, 8, 4008-4042. [CrossRef] [PubMed]

5. Toss, A.; Tomasello, C.; Razzaboni, E.; Contu, G.; Grandi, G.; Cagnacci, A.; Schilder, R.J.; Cortesi, L. Hereditary ovarian cancer: Not only BRCA 1 and 2 genes. BioMed Res. Int. 2015, 2015, 341723. [CrossRef] [PubMed]

6. Williams, T.I.; Toups, K.L.; Saggese, D.A.; Kalli, K.R.; Cliby, W.A.; Muddiman, D.C. Epithelial ovarian cancer: Disease etiology, treatment, detection, and investigational gene, metabolite, and protein biomarkers. J. Proteome Res. 2007, 6, 2936-2962. [CrossRef] [PubMed]

7. Ho, G.Y.; Woodward, N.; Coward, J.I. Cisplatin versus carboplatin: Comparative review of therapeutic management in solid malignancies. Crit. Rev. Oncol. Hematol. 2016, 102, 37-46. [CrossRef]

8. Rabik, C.A.; Dolan, M.E. Molecular mechanisms of resistance and toxicity associated with platinating agents. Cancer Treat. Rev. 2007, 33, 9-23. [CrossRef]

9. Marullo, R.; Werner, E.; Degtyareva, N.; Moore, B.; Altavilla, G.; Ramalingam, S.S.; Doetsch, P.W. Cisplatin induces a mitochondrial-ROS response that contributes to cytotoxicity depending on mitochondrial redox status and bioenergetic functions. PLoS ONE 2013, 8, e81162. [CrossRef]

10. He, P.J.; Ge, R.F.; Mao, W.J.; Chung, P.S.; Ahn, J.C.; Wu, H.T. Oxidative stress induced by carboplatin promotes apoptosis and inhibits migration of HN-3 cells. Oncol. Lett. 2018, 16, 7131-7138. [CrossRef]

11. Lopes-Coelho, F.; Gouveia-Fernandes, S.; Gonçalves, L.G.; Nunes, C.; Faustino, I.; Silva, F.; Félix, A.; Pereira, S.A.; Serpa, J. HNF1beta drives glutathione (GSH) synthesis underlying intrinsic carboplatin resistance of ovarian clear cell carcinoma (OCCC). Tumour Biol. 2016, 37, 4813-4829. [CrossRef] [PubMed]

12. Nunes, S.C.; Lopes-Coelho, F.; Gouveia-Fernandes, S.; Ramos, C.; Pereira, S.A.; Serpa, J. Cysteine boosters the evolutionary adaptation to $\mathrm{CoCl}_{2}$ mimicked hypoxia conditions, favouring carboplatin resistance in ovarian cancer. BMC Evol. Biol. 2018, 18, 97. [CrossRef] [PubMed]

13. Nunes, S.C.; Ramos, C.; Lopes-Coelho, F.; Sequeira, C.O.; Silva, F.; Gouveia-Fernandes, S.; Rodrigues, A.; Guimarães, A.; Silveira, M.; Abreu, S.; et al. Cysteine allows ovarian cancer cells to adapt to hypoxia and to escape from carboplatin cytotoxicity. Sci. Rep. 2018, 8, 9513. [CrossRef]

14. Johnson, S.W.; Ozols, R.F.; Hamilton, T.C. Mechanisms of drug resistance in ovarian cancer. Cancer 1993, 71 , 644-649. [CrossRef]

15. Mytilineou, C.; Kramer, B.C.; Yabut, J.A. Glutathione depletion and oxidative stress. Parkinsonism Relat. Disord. 2002, 8, 385-387. [CrossRef]

16. Franklin, C.C.; Backos, D.S.; Mohar, I.; White, C.C.; Forman, H.J.; Kavanagh, T.J. Structure, function, and post-translational regulation of the catalytic and modifier subunits of glutamate cysteine ligase. Mol. Aspects Med. 2009, 30, 86-98. [CrossRef] [PubMed]

17. Nunes, S.C.; Serpa, J. Glutathione in Ovarian Cancer: A Double-Edged Sword. Int. J. Mol. Sci. 2018, 19, 1882. [CrossRef] [PubMed] 
18. Godwin, A.K.; Meister, A.; O'Dwyer, P.J.; Huang, C.S.; Hamilton, T.C.; Anderson, M.E. High resistance to cisplatin in human ovarian cancer cell lines is associated with marked increase of glutathione synthesis. Proc. Natl. Acad. Sci. USA 1992, 89, 3070-3074. [CrossRef] [PubMed]

19. Lu, S.C. Glutathione synthesis. Biochim. Biophys. Acta 2013, 1830, 3143-3153. [CrossRef]

20. Biterova, E.I.; Barycki, J.J. Structural basis for feedback and pharmacological inhibition of Saccharomyces cerevisiae glutamate cysteine ligase. J. Boil. Chem. 2010, 285, 14459-14466. [CrossRef]

21. Janaszewska, A.; Lazniewska, J.; Trzepiński, P.; Marcinkowska, M.; Klajnert-Maculewicz, B. Cytotoxicity of Dendrimers. Biomolecules 2019, 9, 330. [CrossRef] [PubMed]

22. Restani, R.B.; Morgado, P.I.; Ribeiro, M.P.; Correia, I.J.; Aguiar-Ricardo, A.; Bonifácio, V.D.B. Biocompatible polyurea dendrimers with $\mathrm{pH}$-dependent fluorescence. Angew. Chem. 2012, 51, 5162-5165. [CrossRef] [PubMed]

23. Restani, R.B.; Conde, J.; Pires, R.F.; Martins, P.; Fernandes, A.R.; Fernandes, P.V.; Bonifácio, V.D.B.; Aguiar-Ricardo, A. POxylated Polyurea Dendrimers: Smart Core-Shell Vectors with IC50 Lowering Capacity. Macromol. Biosci. 2015, 15, 1045-1051. [CrossRef] [PubMed]

24. Restani, R.B.; Pires, R.F.; Tolmatcheva, A.; Cabral, R.; Baptista, P.V.; Fernandes, A.R.; Casimiro, T.; Bonifácio, V.D.B.; Aguiar-Ricardo, A. POxylated Dendrimer-Based Nano-in-Micro Dry Powder Formulations for Inhalation Chemotherapy. ChemistryOpen 2018, 7, 772-779. [CrossRef]

25. Restani, R.B.; Conde, J.; Baptista, P.V.; Cidade, M.T.; Bragança, A.M.; Morgado, J.; Correia, I.J.; Aguiar-Ricardo, A.; Bonifácio, V.D.B. Polyurea dendrimer for efficient cytosolic siRNA delivery. RSC Adv. 2014, 4, 54872-54878. [CrossRef]

26. Restani, R.B.; Silva, A.S.; Pires, R.F.; Cabral, R.; Correia, I.J.; Correia, T.; Bonifácio, V.D.B.; Aguiar-Ricardo, A. Nano-in-micro POxylated polyurea dendrimers and chitosan dry powder formulations for pulmonary delivery. Part. Part. Syst. Charact. 2016, 333, 851-858. [CrossRef]

27. Rajani, C.B.; Borisaa, P.; Karanwada, T.; Boradea, Y.; Patela, V.; Rajpootb, K.; Tekadec, R.K. Cancer-targeted chemotherapy: Emerging role of the folate anchored dendrimer as drug delivery nanocarrier. In Pharmaceutical Applications of Dendrimers; Chauhan, A., Kulhari, H., Eds.; Elsevier: Cambridge, MA, USA, 2020; pp. 151-198.

28. Santos, I.; Ramos, C.; Mendes, C.; Sequeira, C.O.; Tomé, C.S.; Fernandes, D.G.; Mota, P.; Pires, R.F.; Urso, D.; Hipólito, A.; et al. Targeting Glutathione and Cystathionine beta-Synthase in Ovarian Cancer Treatment by Selenium-Chrysin Polyurea Dendrimer Nanoformulation. Nutrients 2019, 11, 2523. [CrossRef]

29. Kabil, O.; Banerjee, R. Enzymology of H2S biogenesis, decay and signaling. Antioxid. Redox Signal. 2014, 20, 770-782. [CrossRef]

30. Rizzo, A.; Napoli, A.; Roggiani, F.; Tomassetti, A.; Bagnoli, M.; Mezzanzanica, D. One-Carbon Metabolism: Biological Players in Epithelial Ovarian Cancer. Int. J. Mol. Sci. 2018, 19, 2092. [CrossRef]

31. Mota, P.; Pires, R.F.; Serpa, J.; Bonifácio, V.D.B. L-Buthionine Sulfoximine Detection and Quantification in Polyurea Dendrimer Nanoformulations. Molecules 2019, 24, 3111. [CrossRef]

32. Wang, X.; Yang, R.; Yuan, C.; An, Y.; Tang, Q.; Chen, D. Preparation of Folic Acid-Targeted Temperature-Sensitive Magnetoliposomes and their Antitumor Effects In Vitro and In Vivo. Targeted Oncol. 2018, 13, 481-494. [CrossRef] [PubMed]

33. Siddik, Z.H. Cisplatin: Mode of cytotoxic action and molecular basis of resistance. Oncogene 2003, 22, 7265-7279. [CrossRef]

34. Marengo, B.; De Ciucis, C.; Verzola, D.; Pistoia, V.; Raffaghello, L.; Patriarca, S.; Balbis, E.; Traverso, N.; Cottalasso, D.; Pronzato, M.A.; et al. Mechanisms of BSO (L-buthionine-S,R-sulfoximine)-induced cytotoxic effects in neuroblastoma. Free Radic. Biol. Med. 2008, 44, 474-482. [CrossRef] [PubMed]

35. Chen, Y.; Ji, L.; Xiong, A.; Yang, L.; Wang, Z. Involvement of intracellular glutathione in regulating isoline-induced cytotoxicity in human normal liver L-02 cells. Toxicol. Ind. Health 2013, 29, 567-575. [CrossRef] [PubMed]

36. Liebmann, J.E.; Hahn, S.M.; Cook, J.A.; Lipschultz, C.; Mitchell, J.B.; Kaufman, D.C. Glutathione depletion by L-buthionine sulfoximine antagonizes taxol cytotoxicity. Cancer Res. 1993, 53, 2066-2070.

37. Prezioso, J.A.; FitzGerald, G.B.; Wick, M.M. Melanoma cytotoxicity of buthionine sulfoximine (BSO) alone and in combination with 3,4-dihydroxybenzylamine and melphalan. J. Invest. Dermatol. 1992, 99, $289-293$. [CrossRef] 
38. Tagde, A.; Singh, H.; Kang, M.H.; Reynolds, C.P. The glutathione synthesis inhibitor buthionine sulfoximine synergistically enhanced melphalan activity against preclinical models of multiple myeloma. Blood Cancer J. 2014, 4, e229. [CrossRef]

39. Du, M.; Zhang, L.; Scorsone, K.A.; Woodfield, S.E.; Zage, P.E. Nifurtimox Is Effective Against Neural Tumor Cells and Is Synergistic with Buthionine Sulfoximine. Sci. Rep. 2016, 6, 27458. [CrossRef]

40. Lee, M.; Jo, A.; Lee, S.; Kim, J.B.; Chang, Y.; Nam, J.Y.; Cho, H.; Cho, Y.Y.; Cho, E.J.; Lee, J.-H.; et al. 3-bromopyruvate and buthionine sulfoximine effectively kill anoikis-resistant hepatocellular carcinoma cells. PLoS ONE 2017, 12, e0174271. [CrossRef]

41. Hernandez-Breijo, B.; Monserrat, J.; Ramírez-Rubio, S.; Cuevas, E.P.; Vara, D.; Díaz-Laviada, I.; Fernández-Moreno, M.D.; Román, I.D.; Gisbert, J.P.; Guijarro, L.G. Preclinical evaluation of azathioprine plus buthionine sulfoximine in the treatment of human hepatocarcinoma and colon carcinoma. World J. Gastroenterol. 2011, 17, 3899-3911. [CrossRef]

42. Lewis-Wambi, J.S.; Kim, H.R.; Wambi, C.; Patel, R.; Pyle, J.R.; Klein-Szanto, A.J.; Jordan, V.C. Buthionine sulfoximine sensitizes antihormone-resistant human breast cancer cells to estrogen-induced apoptosis. Breast Cancer Res. 2008, 10, R104. [CrossRef] [PubMed]

(C) 2020 by the authors. Licensee MDPI, Basel, Switzerland. This article is an open access article distributed under the terms and conditions of the Creative Commons Attribution (CC BY) license (http://creativecommons.org/licenses/by/4.0/). 